\title{
The Place of Corrective Feedback Within the Major SLA Theories
}

\author{
Eva Kartchava \\ Université de Montréal, Montreal, Canada
}

\begin{abstract}
Explaining how people learn L2 (second language) is the central task of the SLA (second language acquisition) field. Many theories have been proposed to account for phenomena particular to SLA. Corrective feedback—teachers' feedback in reaction to a student's ill-formed response (Sheen, 2011) —is such a phenomenon, whose relevance is evidenced by a large body of research investigating its various facets (e.g., types, distribution, noticeability, and effectiveness). However, to date, no review of the place of feedback within each of the major SLA theories and the different corrective techniques advocated and/or employed by each has been produced. The purpose of this paper is to bridge this gap by reviewing the major current theories of SLA as they relate to corrective feedback.
\end{abstract}

Keywords: corrective feedback, language acquisition theory, recasts, prompts, explicit feedback, English as an L2 (second language)

\section{Introduction}

Since "theories are a fundamental staple in science, and all advances in science are, in some way or another, advances in theory development” (VanPatten \& Williams, 2007a, p. 1), it is reasonable to assume that no science would evolve, or even exist, if there was no theorizing about its observable facts. Still, since making sense of things lies at the very core of the human cognitive make up (Popper, 2008), isolating, defining, and interpreting sensed phenomena (Jordan, 2004) are perhaps as central a preoccupation of the human brain as can be. While observation ignites the fire of theory creation, theory, in turn, guides the search for and interpretation of data that is likely to explain the phenomena in question. Indeed, one responsibility of a theory is to inform and guide research (McLaughlin, 1987) so that it can strengthen or disclaim any existing explanations of what has been widely observed. Another responsibility is to arrive at these explanations by means of various methods and by multiple perspectives (Larsen-Freeman \& Long, 1991; Long, 2007; McLaughlin, 1987). Thus, theories that are informative, rigorous, and varied are necessary to advance progress in any field of scientific inquiry.

The field of SLA (second language acquisition) research has also accorded theories a central role in advancing the current understanding of how people learn an L2 (second language). Despite some opposition (Larsen-Freeman \& Long, 1991; Long, 1993), there is a general consensus that active but critical theorizing is potentially the best way to achieve progress in the field (Long, 2007; VanPatten \& Williams, 2007a). A number of theories that strive to explain the nature of L2 knowledge and interlanguage development, the 
contributions of knowledge of the L1 (first language), the linguistic environment, instruction (Ortega, 2007), as well as SLA process itself have been proposed in the last 40 years. Although they vary in a number of ways-source, scope, content, type, and form (Long, 2007) - these theories provide SLA scholars with “interim understandings of natural phenomena [...] in the absence of certainty” (Long, 2007, p. 22) and, as such, are instrumental in identifying not only the pertinent variables to study, but also in suggesting foci for future research inquiry.

CF (corrective feedback) - "any reaction of the teacher which clearly transforms, disapprovingly refers to, or demands improvement of the learner's utterance" (Chaudron, 1977, p. 31) —is one such variable. Its relevance lies in its role of raising awareness in the SLA process and its prominence is evidenced by a large body of research conducted both in and out of the classroom. Since the mid-1990s, studies investigating CF have focused on three areas of interest: (1) different feedback techniques and their distribution (e.g., Lyster \& Ranta, 1997; Panova \& Lyster, 2002; Sheen, 2004); (2) the noticeability of these techniques (e.g., Egi, 2007; Kim \& Han, 2007; Mackey, Gass, \& McDonough, 2000; Mackey, Philp, Egi, Fujii, \& Tasumi, 2002; Philp, 2003; Trofimovich, Ammar, \& Gatbonton, 2007; Sheen, 2004); and (3) the effectiveness of CF and various feedback types on SLA (e.g., Ammar, 2008; Ammar \& Spada, 2006; Doughty \& Varela, 1998; Ellis, Loewen, \& Erlam, 2006; Lyster, 2004; Sheen, 2007; Carroll \& Swain, 1993; Leeman, 2003; Lyster \& Izquierdo, 2009; Mackey \& Philp, 1998; McDonough, 2005, 2007). However, to date, there has been no review of the place of feedback within each of the major SLA theories and the different corrective techniques advocated and/or employed by each. The purpose of this paper is to bridge this gap by reviewing the major current theories of SLA as they relate to CF.

\section{CF Techniques}

Recasts, explicit feedback, elicitation, metalinguistic feedback, repetition, and clarification requests are all CF techniques that have been used in the literature to refer to the ways in which feedback can be provided. The techniques, originally coded by Chaudron (1977), represent the taxonomy developed by Lyster and Ranta (1997) for the L2 classroom and are outlined in Table 1. These six feedback techniques were first re-classified by Lyster (2004) into three categories of: (1) recasts, (2) explicit correction, and (3) prompts, and more recently were regrouped again into "reformulations" and "prompts" by Ranta and Lyster (2007). Recasts and explicit correction were categorized together under "reformulations", because they both supply the learner with either an implicit or explicit reformulation of the target form and are thus input-providing (Ellis, 2006). The "prompt" category, in turn, comprises four output-promoting (Ellis, 2006) corrective techniques (metalinguistic feedback, elicitation, repetition, and clarification request), all of which are designed to push learners to recognize the corrective intent of CF and to help them fix the error on their own. It is important to remember, however, that each category can differ greatly in terms of implementation and the degree of explicitness/implicitness of the technique (Ellis et al., 2006).

\section{Major SLA Theories and CF}

Researchers generally agree on 10 key theories that explain the linguistic and cognitive aspects of SLA (VanPatten \& Williams, 2007a): Behaviourism, Nativism/Innatism, Autonomous Induction Theory, Associative-Cognitive CREED Framework, Skill Acquisition Theory, Input Processing Theory, Processability Theory, Concept-Oriented Approach, Interaction Framework, and Vygotskian Sociocultural Theory. However, 
only those SLA theories that explain the role of error and feedback in L2 learning will be considered and explained here. The Behaviourism, Nativism/Innatism, Interactionism, and Cognitive/Psycholinguistic theories are believed to represent this goal well, since they embody both the early and current understandings of the feedback process.

Table 1

CF Techniques (based on Lyster \& Ranta, 1997)

\begin{tabular}{|c|c|c|c|c|}
\hline & Technique & Definition & Example & \\
\hline \multirow{2}{*}{$\begin{array}{l}\text { Teacher } \\
\text { corrects }\end{array}$} & Recasts & $\begin{array}{l}\text { “Teacher's reformulation of all or part of a } \\
\text { S’s utterance minus the error” (p. 46). }\end{array}$ & $\begin{array}{l}\text { In response to a student’s incorrect } \\
\text { statement of “I have many book", the } \\
\text { teacher may recast as follows “Oh, you } \\
\text { have many books". }\end{array}$ & \\
\hline & $\begin{array}{l}\text { Explicit } \\
\text { correction }\end{array}$ & $\begin{array}{l}\text { "Explicit provision of the correct form” by } \\
\text { the teacher (p. 46). }\end{array}$ & $\begin{array}{l}\text { Student: “I have many book”; } \\
\text { Teacher: “We don’t say book [stressed]. } \\
\text { You should say books [stressed]. }\end{array}$ & \\
\hline \multirow{4}{*}{$\begin{array}{l}\text { Student } \\
\text { self-corrects }\end{array}$} & $\begin{array}{l}\text { Metalinguistic } \\
\text { feedback }\end{array}$ & $\begin{array}{l}\text { "Contains comments, information or } \\
\text { questions related to the well-formedness of } \\
\text { the S's utterance, without explicitly } \\
\text { providing the correct form” (p. 47). }\end{array}$ & $\begin{array}{l}\text { Student: “I have many book"; } \\
\text { Teacher: "No, not book [stressed]. It’s } \\
\text { supposed to be in plural. How do we form } \\
\text { plural in English?”. }\end{array}$ & \multirow{4}{*}{ Prompts } \\
\hline & Elicitation & $\begin{array}{l}\text { Teachers either: (1) elicit "completion of } \\
\text { their own utterance by strategically pausing } \\
\text { to allow Ss to fill in the blank", (2) use } \\
\text { "questions to elicit correct forms", or (3) ask } \\
\text { Ss to "reformulate their utterance" (p. 48). }\end{array}$ & $\begin{array}{l}\text { Student: "He like coffee"; } \\
\text { Teacher: "He what [stressed] coffee?". }\end{array}$ & \\
\hline & Repetition & $\begin{array}{l}\text { “Teacher's repetition, in isolation, of the S's } \\
\text { erroneous utterance” (p. 48). }\end{array}$ & $\begin{array}{l}\text { Student: “I see a movie yesterday”; } \\
\text { Teacher: “I see [stressed] a movie } \\
\text { yesterday [stressed]?”. }\end{array}$ & \\
\hline & $\begin{array}{l}\text { Clarification } \\
\text { requests }\end{array}$ & $\begin{array}{l}\text { "Indicates to Ss either that their utterance has } \\
\text { been misunderstood by the teacher or that } \\
\text { the utterance is ill-formed in some way and } \\
\text { that a repetition or reformulation is required" } \\
\text { (p. } 47 \text { ). }\end{array}$ & $\begin{array}{l}\text { Student: “He like coffee”; } \\
\text { Teacher: "Pardon me?”. }\end{array}$ & \\
\hline
\end{tabular}

\section{Behaviourism}

Within the behaviourist theory, habit formation was seen as key to learning any skill (Skinner, 1957), and the environment was considered the most important factor in learning. All behaviour was explained as a response to external factors in the environment and not as a function of internal processes. It was believed that learning resulted in the acquisition of new behaviour when it consisted of imitation, practice, and appropriate feedback. While imitation of sounds and structures heard in the environment was the essential first step in learning a language, feedback on production (output) was instrumental in the formation of good habits. In fact, the feedback was a whole system called behavioural conditioning, which trained learners to engage in new behaviors through reinforcement and punishment. That is, positive feedback (reinforcement) would result in the repetition of error-free L2 output by a learner, but negative or non-existent reaction (punishment) would make replication of such behaviour less probable. As such, active and repeated engagement in the target behavior was considered crucial to the learning process. The behaviourist approach to language learning and teaching was closely linked to structural linguistics, which viewed language as based on a finite set of predictable patterns. Thus, the learner's job was to imitate and internalize predetermined linguistic patterns without having to think about what he/she was doing, since learners were seen as receivers of language, programmed to listen and repeat what they heard in as error-free a fashion as possible. 
The behaviourist theory suggested direct and tangible pedagogical practices and stressed the importance of correct models, practice, and feedback. The importance of CF lay in the belief that successful L2 learning could only be achieved through the eradication of old habits (i.e., errors) and the formation of new (correct) ones. That is, errors were believed to impede the learning process. As such, teachers would not allow learners to engage in spontaneous speech, fearing that they would make errors, which could then develop into bad habits if left untreated. Instead, teachers provided correct models, ensured abundant repetition without learner reflection, did everything to avoid errors in the student output, and provided appropriate feedback. In fact, language teachers trained in the Audiolingual Method were instructed to avoid errors at all costs. If an error did occur, the teachers were told to "correct student errors immediately, use reinforcement, use repetition and imitation till the student masters the problem” (Courchêne, 1980, p. 9). Hence, the treatment of errors was consistent, overt, and immediate. The two CF techniques that seem most compatible with Behaviourism are those that provide the learner with the correct form (i.e., recasts and explicit correction). Recasts supply learners with grammatically correct (full or partial) models of the target language, and explicit feedback signals the presence of an error by providing an overt reformulation of the problem, thus prompting repetition of the correction.

The behaviourist stimulus-response model of language learning and the structuralist approach to language description were challenged in the 1960s, when the L1 acquisition researchers (Chomsky, 1957, 1966) began to show that the linguistic system was too complex to be learned through imitation alone and that children learning their L1 were able to produce language (and language rules) far richer and more diverse than any sample of language they could have picked up in the input. Furthermore, regardless of any context or other external factors, all children learning their L1 appeared to acquire grammatical features in fixed orders and made only certain kinds of errors instead of making all errors that were theoretically possible. Empirical investigations into the role of negative evidence in L1 acquisition demonstrated that, as a rule, parents rarely paid attention to the form of their children's output, but instead paid more attention to the truth value of what was said (Brown, 1973; Brown \& Hanlon, 1970). These observations led researchers to suggest that language learning was unique and relied on an innate ability available to all humans at birth. According to Chomsky (1957), this innate ability is stimulated by the linguistic input one is exposed to. This input, in turn, shapes one's knowledge of the rules of a given language, which allows for the production of an infinite number of sentences, a large portion of which is unique and, as such, cannot be imitated or rehearsed.

As L1 researchers were transforming the theory of language acquisition, SLA researchers found that Behaviourism, together with Contrastive Analysis ${ }^{1}$, could not predict or explain the errors that L2 learners make. Moreover, grammatical morpheme studies revealed that L2 learners acquired grammatical features in a consistent order and made errors that resembled those made by children learning their L1. This led them to conclude that L2 learning is not dependent on L1, but that it is internally driven and involves unconscious testing of hypotheses derived from the L2 input. Furthermore, largely due to Corder's (1967) influential paper that questioned the place of error in L2 learning, errors were no longer viewed as problems, but as a necessary part of language development. This is because they not only provide evidence of where learners are in respect to the target norms, but they also reveal the process by which L2s are acquired.

\footnotetext{
${ }^{1}$ Contrastive Analysis refers to detailed comparisons of the phonology, morphology, syntax, and even the cultural systems of two languages to determine the similarities and differences between the two. Similarities between the structures were seen as the candidates for positive transfer because learners would not need to change their old habits but would simply apply them "as is" to a new context. Negative transfer, however, signalled differences between the languages, resulting in learners' difficulty (errors).
} 


\section{Nativism/Innatism}

Stephen Krashen's Monitor Theory (1982) was the first innatist theory developed specifically for SLA. Although Krashen has never openly stated this, many in the field believe that his theory is based on Chomsky's theory of language (e.g., Gass \& Selinker, 2001; Larsen-Freeman \& Long, 1991; VanPatten \& Williams, 2007b). The connection between the two theories lies in their shared belief that humans possess a unique innate ability to learn languages-Chomsky's "the language acquisition device". Krashen argued that this ability is not exclusive to L1 but that, under appropriate conditions, it can also extend to SLA. According to his model, which comprises five interrelated hypotheses ${ }^{2}$, the only thing needed for SLA to occur is for a learner to be exposed to comprehensible input that he/she can: (1) readily process for meaning; and (2) learn from. Krashen suggested that comprehensible input is readily available to learners by means of listening and reading texts, and that if the content is relevant and learners are able to comprehend its meaning, grammar learning will happen naturally and CF will not be necessary. Krashen based this role for input on L1 acquisition research that claimed that "in order to build an L1 grammar, children only need to be exposed to the language that parents or caretakers direct them to for the purpose of meaning making” (Ortega, 2009, p. 60).

According to Krashen's acquisition-learning hypothesis, L2 learners have two independent ways to develop L2 knowledge: subconsciously (acquisition) and consciously (learning). Acquisition is subconscious in both process and product. The process of acquisition is similar to the way children learn their L1 in that learners acquire language without being aware of it. The only thing they are aware of is that they are using the language to communicate meaning and as such, all their attention is focused on the task at hand. The result of acquisition (product) is also subconscious, because "we are generally not consciously aware of the rules of the languages we have acquired. Instead, we have a 'feel' for correctness. Grammatical sentences 'sound' right, or 'feel' right, and errors feel wrong, even if we do not consciously know what rule was violated” (Krashen, 1982, p. 10). Unlike acquisition, learning is conscious in both process and product. The process of learning is through intentional study of the L2 rules and patterns, resulting in explicit knowledge of the "grammar" or "rules" of the language. Interestingly, these two systems can never interact; knowledge gained by means of one system can never be transferred or incorporated into another for the purpose of spontaneous use. Instead, each system functions independently and has a different task to perform: The acquired system is used to produce language, and the learned knowledge monitors the resulting output.

Since Krashen saw acquisition as central in language learning, the learned system only had a peripheral role to play. Its primary function was to monitor the acquired knowledge during language production. This "Monitor", however, could not be used at all times; it could only be activated when three conditions were met: (1) Learners needed to have enough time to access the learned system; (2) They also had to focus on form (not just the meaning) of what they were saying; and (3) Their learned system needed to be rich enough to allow for the retrieval of case-appropriate rules. Thus, the Monitor can only be used in situations when it does not interfere with communication (e.g., writing or test-like tasks).

The natural order hypothesis states that L2 learners acquire grammatical morphemes (e.g., -ing, -s, -ed) in a predictable order, regardless of their L1 and whether or not they received instruction. The "natural order" originates in the acquired system and receives no interference from the learned system. It has been argued that

\footnotetext{
2 The five hypotheses of Krashen's monitor model are: (1) the acquisition-learning hypothesis; (2) the monitor hypothesis; (3) the natural order hypothesis; (4) the input hypothesis; and (5) the affective filter hypothesis.
} 
the "order" is regular across L2 learners, because all language acquisition is guided by the innate human language learning ability.

Given that there is a natural order of acquisition, how do learners move from one point to another? According to Krashen, L2s are acquired by "understanding messages or by receiving 'comprehensible input'” (Krashen, 1985, p. 2), which he defined as language that is slightly above the learner's current grammatical knowledge. This type of input was represented as “ $i+1$ ”, where " $i$ ” referred to the learner's current interlanguage level and " $i+1$ ” identified a point just above the learner's current level. Krashen considered comprehensible input as the most valuable for SLA, since exposure to input that is both comprehensible and comprehended allows for the spontaneous acquisition of the L2 to take place. As such, instruction that focused on meaning instead of form was promoted, and learners were encouraged to produce language only when they felt ready to do so, since premature (and forced) production was believed to inhibit the acquisition process by taking learners' attention away from the primary task of communication. In short, for SLA to occur, one simply needs access to his/her innate language ability and exposure to rich comprehensible input. Furthermore, if comprehensible input is available, SLA is inevitable (VanPatten \& Williams, 2007b).

Finally, in his affective filter hypothesis, Krashen states that in order for L2 learners to acquire language, they need to feel comfortable and be receptive to the input they are exposed to. Factors such as motivation, attitude, self-confidence, and anxiety can all affect the success of language learning. Krashen thus proposed the affective filter construct; learners whose filters are "down" are more likely to feel comfortable and motivated to learn an L2, allowing for comprehensible input to flow in freely and for acquisition to occur. If the filter is "up", however, learners are likely to block the input, thus preventing acquisition from taking place. Stressful environments where learners are asked to pay attention to form and/or are forced to produce language before they are ready to do so characterize high affective filter situations and need to be avoided. According to Krashen, for successful language acquisition to occur, two conditions are necessary: (1) rich comprehensible input (at the right level); and (2) a low/weak affective filter.

While the behaviourist theory profusely advocated CF, Krashen's Monitor Theory shied away from it altogether. Krashen argued against treatment of errors that did not impede understanding of the intended message, saying that although CF may be helpful, comprehensible input alone is sufficient for SLA. According to his model, knowledge that entails deliberate attention to form as well as formal instruction can be used only to monitor (i.e., make minor form-related changes) the output generated by the acquired system. Furthermore, since the monitor is not always available during communicative tasks, feedback to form may be of little use, since even if it is provided, nothing can guarantee that learners will notice, understand, and adopt it. As such, Krashen maintained that learners should be engaged in tasks that are rich in comprehensible input and that provide opportunities for meaningful interaction instead of those that focus on instruction of grammatical categories and include feedback on errors. Truscott (1996) went even further to claim that grammar teaching and CF are to be avoided, as they are likely to result in the breakdown of the communicative flow.

Krashen's theory that comprehensive input alone is enough for successful language learning has been challenged (e.g., Long, 1991, 1996; Swain, 1985, 1993, 1995; White, 1987). It has been suggested that attention to form is necessary "if native-like proficiency is the goal" (Long, 1996, p. 423). Several studies, conducted in both natural and classroom contexts (e.g., Harley \& Swain, 1984; Lightbown \& Spada, 1994; Sato, 1990; Schmidt, 1983; Schmidt \& Frota, 1986; Swain, 1985), have demonstrated that despite abundant exposure to comprehensible input and ample opportunities to use L2 in meaningful ways, the learners' grammatical 
development was minimal. For example, in his well-known case study of Wes, a young Japanese artist, Schmidt (1983) reported a remarkable transformation in the communicative ability of someone who arrived in the United States with limited L2 skills and who was able, in the course of a three-year intensive exposure to the L2 input, to carry on conversations as well as to conduct all of his dealings entirely in English. Despite his success, Wes' speech fell short in terms of accuracy, which Schmidt attributed to the lack of formal instruction and Wes’ preference for “message content over message form” (p. 169). A lack of instruction in the L2 norms has also been blamed for the low grammatical accuracy among learners in immersion (Harley \& Swain, 1984; Swain, 1985) and highly communicative intensive ESL (English as a Second Language) contexts (Lightbown \& Spada, 1990, 1994), where the primary focus is placed on the communication of meaning and interaction. This research has shown that students enrolled in purely communicative classes attained advanced abilities in reading and listening skills (and even fluency), but failed to achieve native-like accuracy in writing and speaking. Hence, researchers agree that while input is necessary in SLA, it is not enough on its own, and that other factors are needed to explain the processes involved. Several theories have been put forth to explain additional sources of L2 learning. Of these, the interactional and psycho-cognitive theories will be detailed next.

\section{Interactionism}

In today's communicative classrooms, much of the L2 input is through oral interaction with one or more interlocutors. Thus, modifications to one's speech are important for successful communication. These modifications are initiated by either of the speakers, who, having perceived a comprehension problem, adjusts his/her speech to make the intended meaning more comprehensible. This process of meaning adjustment, termed "negotiation for meaning", has become the primary tenet of the Interaction Hypothesis, proposed by Michael Long (1983, 1991, 1996). The original formulation of the Hypothesis (1983) argued that it is modified interaction (e.g., linguistic simplification, slower speech rate, gestures, and contextual clues) that renders input comprehensible, and in turn promotes SLA. While there is agreement regarding the positive effects interaction has on comprehension in general (e.g., Doughty \& Pica, 1986) and on language development in particular (e.g., Mackey \& Philp, 1998), Pica (1994) has identified an additional way in which interaction may encourage language learning. She observed that whenever an interlocutor could not understand the intended meaning, he/she would signal the problem by using the following negotiation strategies: clarification requests, confirmation checks, comprehension checks, and recasts. While clarification requests (e.g., what?, uh?, pardon me?) elicit an explanation of the interlocutor's preceding utterances, comprehension checks (e.g., do you want me to repeat?, did you understand?) verify that the intended message has been understood. Confirmation requests (e.g., a base?, you mean $X$ ?), in turn, are used to elicit confirmation that the interlocutor has correctly understood the message. Finally, recasts provide a correct reformulation of an erroneous utterance while maintaining the original meaning intact. These interactional moves, Pica argued, were instrumental in alerting the learner that a breakdown in communication has occurred and that a reformulation or clarification is needed. Furthermore, the learner's recognition of the problem could invoke noticing, which would then lead to L2 learning (Schmidt, 1990, 2001; Schmidt \& Frota, 1986). This view was also advocated by Gass (1997), who claimed that interaction can draw the learner's attention to linguistic problems and that noticing of mismatches between input and learner's output is the first step in interlanguage development.

These observations, along with Swain's Comprehensible Output Hypothesis (detailed below), led Long to revise his Interaction Hypothesis (1996) by giving CF more importance. In his revised Hypothesis, Long 
asserted that information about the correctness, and more importantly, the incorrectness of learners' utterances received through interaction leads to greater SLA. Thus, in its new form, this Hypothesis claims that modified input coupled with CF obtained through interaction bring about L2 learning.

Swain (1985) took the idea of interaction modification further by positing that output is inevitable in the L2 development process. Prior to her Comprehensible Output Hypothesis, output was seen as a way to practice already-existing knowledge or to elicit additional input (Krashen, 1985) and not as a way to create knowledge. Swain argued that learners need to be pushed to produce L2 in a precise, coherent, and appropriate fashion. This is important because:

Output may stimulate learners to move from the semantic, open-ended, nondeterministic, strategic processing prevalent in comprehension to the complete grammatical processing needed for accurate production. Output, thus, would seem to have a potentially significant role in the development of syntax and morphology. (Swain, 1995, p. 128)

Furthermore, Swain (1995) claimed that output serves four functions in the learning process. First, producing output allows learners to test their interlanguage hypotheses about the structures and meanings of the L2, leading either to the reinforcement or rejection of a hypothesis, which ultimately results in language learning. Second, output promotes noticing of gaps (and holes) between what a learner wants to say and what he/she actually says. This noticing, in turn, pushes the learner to direct attention toward the problematic utterances and to revise them. Another function of output is to promote automaticity-that is, control over one's linguistic knowledge-which involves "consistent mapping of the same input to the same pattern of activation over many trials” (McLaughlin, 1987, p. 134). Swain extended this notion to output, claiming that consistent and successful mapping of grammar to output brings about automatic processing, an argument reiterated by DeBot (1996). In other words, continued practice of language ensures more fluent and automatic L2 production. Finally, output carries a metalinguistic function "of using language to reflect on language, allowing learners to control and internalize it” (Swain, 1995, p. 132).

While most interactionist researchers agree that CF is beneficial for learning, they argue as to the techniques that will bring about acquisition. For example, Long $(1996,2007)$ has advocated the use of recasts and the "three C's", namely, Clarification requests, Confirmation checks, and Comprehension checks (Gass \& Mackey, 2007). Because of their implicit and reactive nature, these techniques lend themselves well to communicative classrooms, where the focus is primarily on meaning and communication. Long claims that CF needs to be reactive and should only occur when teachers or other learners perceive difficulty in understanding the message or its form (Long \& Robinson, 1998). Recently, interaction research has, in some cases, replaced the "three C's" with recasts as the preferred feedback technique (Gass \& Mackey, 2007). Recasts provide learners with target-like reformulations of the learner's original utterance. They do not need to involve repetition of the entire utterance and may include additional elaborations not present in the original statement, but they are contingent on the learner's utterance, which they temporarily juxtapose. This juxtaposition frees the working memory from processing for meaning, therefore increasing the chances of processing for form. While this juxtaposition is instrumental in simultaneously providing the learner with both positive (correct form) and negative evidence (non-target-like form) in an environment where positive evidence is enhanced (i.e., communicative classroom), it may also confuse the learner as to its intent. That is, if a recast occurs after an ungrammatical utterance, it may be perceived as responding to the content of the statement (instead of its form) or even as another way of saying the same thing (Lyster, 1998a, 1998b; Lyster \& Ranta, 1997). Although 
Swain (1985) has not openly advocated one corrective technique over the other, the notion that learners need to be pushed to produce more target-like output suggests that prompts are possibly the best way to facilitate L2 learning in that context. Since prompts push learners to correct the error on their own, they are instrumental in focusing the learners' attention on certain aspects of their speech, leading them to notice the gaps and/or holes in their output.

\section{Psycho-Cognitive Theories}

Cognitive SLA theories aim to explain how L2 is processed and learned by the human brain. Unlike the behaviorist stimulus-response model for human learning, cognitive psychologists view the brain as a processor that operates on mental representations, which mediate input and output. Output is measured in terms of performance, which is inferred from observations of information processing. Current SLA research on cognition has adopted three key assumptions made by information processing psychologists: (1) Learning is made of representation and access or process (Skehan, 1998); (2) Mental processing is divided into automatic/fluent (unconscious) and voluntary/controlled (conscious) modes; and (3) Attention and memory-a central preoccupation in SLA cognition-are limited (Ortega, 2009). To begin, representation refers to knowledge of the L2 in terms of its grammar, lexicon, and schemata. Access involves the processing (i.e., access and retrieval) of that knowledge when it is needed for comprehension (input) or production (output). This processing is supported by both automatic and controlled mechanisms, which create all human perception and action through interaction. When a task is automatic, its processing requires little effort and, as such, uses few cognitive resources, allowing for simultaneous execution of several tasks (i.e., parallel processing). Controlled processing, on the other hand, involves more effort and cognitive resources, which limits the number of elements one can attend to at the same time (i.e., serial processing). The latter is activated when mental and conscious effort is required to perform any task. This limited capacity model of information processing (Ortega, 2009) predicts that tasks performed under controlled processing will yield a performance that is variable and vulnerable.

To become an effective L2 user, one would need to achieve a certain level of automaticity, i.e., "automatic performance that draws on implicit-procedural knowledge and is reflected in fluent comprehension and production and in lower neural activation patterns” (Ortega, 2009, p. 85; Segalowitz, 2003), where he/she will be able to use the language with relative ease and speed. According to the Skill Acquisition Theory, adapted from John Anderson's ACT (Adaptive Control of Thought) theory (Anderson, 1983), learning is the gradual transformation of knowledge from controlled to automatic through repeated practice. That is, over time, practice replaces controlled processes with automatic ones through the conversion of declarative/explicit knowledge into procedural knowledge. While the initial change happens rather quickly, the subsequent automatization of procedural knowledge occurs at a much slower rate. Automatization can be defined in several ways: (1) the whole process of knowledge change (from declarative to procedural); (2) "the slow process of reducing error rate, reaction time, and interference with/from other tasks that takes place after proceduralization"; or (3) "quantitative change in the subcomponents of procedural knowledge to the exclusion of any qualitative change or restructuring” (DeKeyser, 2007a, p. 3). Regardless of the definition one adopts, researchers agree that knowledge developed at the later stage is more specific than at the beginning, oftentimes becoming so specialized that it does not transfer well, even to similar tasks (DeKeyser, 2007b). Thus, the development of the two kinds of knowledge is needed for effective language learning: procedural knowledge 
for use in predictable contexts and declarative knowledge for application of rules in new situations. More important, however, is that the right conditions are present for the automatization of knowledge to succeed. That is, abstract rules need to be repeatedly illustrated with concrete examples (to create mental associations between the two) to move learners from the "that" to the "how" stage of skill acquisition (Anderson, Fincham, \& Douglass, 1997) —and this is precisely what is missing in L2 teaching (DeKeyser, 2005).

A central concept in the study of skill acquisition is the "power law of practice/learning" (DeKeyser, 2007a; 2007b), which states that practice causes reaction time and error rate to decline over time, meaning that practice will stop yielding results at some point (Anderson, 2000). Furthermore, automatization is highly skill-specific and, as such, it should involve practice that focuses on the production/comprehension of relevant abilities (e.g., practice of L2 production will help automatize production, not comprehension). Lastly, it is important to note that proceduralized knowledge is not the same as implicit knowledge. While absence of awareness is a necessary requirement for implicit knowledge, this is not so for automaticity (DeKeyser, 2007a). That is to say that knowledge can be implicit but not automatic (e.g., error rate is high but speed is low due to incomplete implicit learning, which causes the learner to feel unsure about what he/she knows), and vice versa-it can be automatic yet not implicit (speed is high and error rate is low, but the learner is still conscious of the rule).

The third key assumption in the study of cognition in SLA is that although memory and attention play an important role in language learning, their capacity is limited. There are two types of memory available in the human mind: long term and working (short term). Since the former is about representation, its capacity is virtually unlimited. It comprises two types of memory: explicit-declarative, which aids in the recollection of facts and events, and implicit-procedural, which supports skills and habit learning ${ }^{3}$. Working memory, in turn, is about access and involves on-the-spot "working out" (N. Ellis, 2005) of problems. Thus it not only stores information, but also integrates new information with knowledge that has already been encoded in long-term memory. N. Ellis (2005) defined working memory as:

the home of explicit induction, hypothesis formation, analogical reasoning, prioritization, control, and decision-making. It is where we develop, apply, and hone our linguistic insights into an L2. Working memory is the system that concentrates across time, controlling attention in the face of distraction. (p. 337)

Its storage capacity, however, is limited, and stores information for only a few seconds before forgetting it altogether (unless it is practiced enough to enter long-term memory—phonological loop, Baddeley, 2007).

This limitation is offset by attention, which increases the amount of time information remains activated in working memory before it is sent for further processing or for storage in long-term memory. Attention, however, is also limited in capacity, allowing it to handle only one attention-demanding processing task at a time (Ortega, 2009). But what determines the order in which information is processed? In his Input Processing hypothesis, Bill VanPatten (2002, 2004) suggested two principles that guide learners in the processing of input during real time comprehension. First, learners’ process input for meaning before they process it for form. In grammatical terms, this means that: (1) They process content words before anything else (e.g., in "The cat is sleeping”, learners will process “cat” and "sleep” before "the” and “is”, VanPatten, 2007, p. 117); (2) They tend to rely on lexical items as opposed to grammatical form to get meaning when both encode the same semantic

\footnotetext{
${ }^{3}$ Long-term memory can be differentiated further to include semantic memory (knowledge of facts known to everyone) and episodic memory (privately experienced events; see Tulving, 2002).
} 
information (e.g., "yesterday" will be processed before the verb-final "-ed”; "he” before the third person singular marker "-s"); and (3) They interpret the first noun in a sentence to be the subject (e.g., "Mary hates John," Mary = doer = subject, VanPatten, 2007, p. 121). Second, for learners to process form that is not meaningful, they must be able to process informational or communicative content at no or little cost to attention. This means that the learners' attention needs to be drawn to form in ways that ensure awareness.

The importance of awareness in learning an L2 was first highlighted by Schmidt, who proposed the Noticing Hypothesis (Schmidt, 1990). According to this hypothesis, learning any aspect of an L2 requires conscious noticing of the relevant linguistic data in the input. It is focused attention on specific aspects in the input that brings about L2 knowledge: "What learners notice in input is what becomes intake for learning" (Schmidt, 1995, p. 20). In other words, learning all aspects of an L2 cannot occur without awareness. What is more, subliminal learning is impossible (Schmidt, 1990). Schmidt (1990, 1994, 1995, 2001) attributed two levels to awareness: higher and lower. While the higher level of awareness is associated with understanding and is seen as facilitative but not necessary for language learning, the lower level is equated to noticing and is judged as crucial to SLA.

Various positions have been taken on the Noticing Hypothesis (N. Ellis, 2002; Gass, 1997; Robinson, 1995; Schmidt, 2001; Tomlin \& Villa, 1994). Nick Ellis (2002), for example, has sided with Schmidt's position, saying that the Noticing Hypothesis can be deemed "correct", provided that it is complemented by the following two conditions (stipulated in his Implicit Tallying Hypothesis, 2002): (1) Noticing is necessary only for new elements, whose learning cannot be achieved without conscious attention; and (2) Noticing may be necessary only for first, and not for consecutive, encounters with "difficult" elements, because "once a stimulus representation is firmly in existence, that stimulus [...] need never be noticed again; yet as long as it is attended to for use in the processing of future input for meaning, its strength will be incremented and its associations tallied and implicitly catalogued” (N. Ellis, 2002, p. 174). Robinson (1995) also agreed that noticing is a necessary condition for language learning, but specified that this is only so as long as noticing is seen as involving awareness (focal attention) plus rehearsal of input in the short-term memory. The focus here is on the rehearsal function, which is claimed to control the sending of information stored in the short-term memory to the long-term memory.

Others, however, have disagreed with Schmidt, suggesting that only detection is necessary in learning an L2 (Tomlin \& Villa, 1994) and that while noticing facilitates L2 development, it is not required (Gass, 1997; Tomlin \& Villa, 1994). In their functional model of input processing, Tomlin and Villa (1994) divided attention into three components: (1) alertness (a general readiness to deal with the incoming stimuli); (2) orientation (the direction of attention resources to a certain type of stimuli); and (3) detection (the cognitive registration of the stimuli) (p. 190). Of the three, they accord orientation and detection central roles in the process of second language acquisition. For them, "The key idea of orientation is that the specific aligning of attention ('orienting') on a stimulus has facilitative or inhibitory consequences for further processing depending on whether or not information occurs as expected or not as expected” (1994, p. 191). Despite the importance of orientation as a function of attention, Tomlin and Villa argue that it is detection alone that is necessary for acquisition to occur, because once a particular exemplar is registered in memory, the learner can then use it to make and test hypotheses about the L2 standard. As such, the model maintains that while alertness and orientation may increase the chances of detection, they (separately or together) are not necessary for detection to take place (p. 197). In other words, there is no link between learning and awareness; instead, it is the 
detection of linguistic input (without awareness) that is necessary to ensure L2 learning. Similarly, Gass (1997) claimed that although noticing is helpful in L2 learning, it is not essential.

In light of this, Schmidt adjusted his original claim of noticing being the "necessary and sufficient condition for converting input to intake” (Schmidt, 1990, p. 129) to assigning it a facilitative role in L2 learning. Thus, in its present form, the Noticing Hypothesis states that noticing is helpful in L2 learning and that "more noticing leads to more learning” (Schmidt, 1994, p. 18). Noticing can come from within the learner or can be encouraged by external factors, such as a lesson or a reaction from the teacher/interlocutor. These factors make learners become aware of: (1) the forms in the target language (Schmidt, 1995); (2) the gaps between their utterances and the L2; and (3) the holes (what is missing) in their interlanguage (Swain \& Lapkin, 1995). In this weaker form, the Hypothesis has attracted much support among researchers, who, for the most part, have been able to demonstrate that noticing (detection plus awareness) is facilitative of L2 learning.

In terms of the corrective techniques, the theories herein do not explicitly subscribe to one type over the other, but simply reiterate the importance of feedback as an awareness-raising tool. However, it may be possible to conclude that VanPatten's Hypothesis advocates recasts. Since learners (especially low-level learners) cannot attend to meaning and form simultaneously, one of the potential benefits of recasts is that they keep the meaning constant. Once the meaning is understood (even if partially), the resources needed to process meaning will be reduced, allocating more attention to form, and consequently, facilitating form-function mapping (VanPatten, 1990). Furthermore, in relation to cognitive psychology, prompts may also be seen as a "good" CF technique as they can help with proceduralizing declarative knowledge and automatizing retrieval of correct forms (DeBot, 1996). In other words, recasts may be advantageous for first-time encounters, because they can serve as models of what is possible in the target language. Once these models are provided, prompts may be employed to push learners to retrieve these correct forms from declarative knowledge to proceduralize them and to make their retrieval automatic.

\section{Conclusions}

The four theories described here represent different views on the process of L2 learning and the role of CF in this process. The behaviourist viewpoint suggests that language is learned through imitation of the supplied models and errors are to be avoided for successful acquisition. If errors occur, the best way to treat them is through immediate and overt correction that includes the identification and remediation of the problem as well as the provision of additional target-like models. Hence, recasts and explicit correction are the preferred techniques to remedy ill-formed utterances-recasts provide the models of the target form, and explicit correction signals the locus of the error, explains the problem in grammatical terms, and ensures ample repetition of the correction. Innatists, on the other hand, believe in the sufficiency of comprehensible input and see no need for grammar teaching or $\mathrm{CF}$, which instead of promoting acquisition, impede it by raising the affective filter, decreasing motivation, and interrupting the flow of communication. Arguing against the sufficiency of comprehensible input in SLA, interactionists agree on the importance of having the learners' attention drawn to the formal properties of the target language by means of feedback. Their theoretical stances, however, imply different corrective techniques. While some (Long, 1996, 2007) see recasts as effective in that they are implicit and are provided in reaction to a comprehension or production "roadblock", others (Swain, $1985,1995)$ seem to prefer pushing learners to produce output, which may favour prompts over recasts. Finally, although the psycho-cognitive theories have not made explicit claims about which CF techniques bring about 
more language learning, they see both recasts and prompts as important, though at different stages in the language learning process. CF is attributed an important role in these types of theories, as it draws the learners' attention to form during communication and thus allows them to notice the gap between what they said and what they meant to say. While the major language theories advocated today generally agree on the facilitative effect of CF on language learning, there is no consensus on whether certain feedback techniques are more effective than others in leading to learning gains—a question that can only be answered empirically.

\section{References}

Ammar, A. (2008). Prompts and recasts: Differential effects on second language morphosyntax. Language Teaching Research, 12, 183-210.

Ammar, A., \& Spada, N. (2006). One size fits all? Recasts, prompts and L2 learning. Studies in Second Language Acquisition, 28, 543-574.

Anderson, J. R. (1983). The architecture of cognition. Cambridge, M.A.: Harvard University Press.

Anderson, J. R. (2000). Learning and memory: An integrated approach (2nd ed.). New York, N.Y.: Wiley.

Anderson, J. R., Fincham, J. M., \& Douglass, S. (1997). The role of examples and rules in the acquisition of a cognitive skill. Journal of Experimental Psychology: Learning, Memory, and Cognition, 23(4), 932-945.

Baddeley, A. D. (2007). Working memory, thought and action. Oxford: Oxford University Press.

Brown, R. (1973). A first language: The early stages. Cambridge, M.A.: Harvard University Press.

Brown, R., \& Hanlon, C. (1970). Derivational complexity and order of acquisition in child speech. In J. R. Hayes (Ed.), Cognition and the development of language (pp. 11-53). New York, N.Y.: Wiley.

Carroll, S., \& Swain, M. (1993). Explicit and implicit negative feedback: An empirical study of the learning of linguistic generalizations. Studies in Second Language Acquisition, 15, 357-386.

Chaudron, C. (1977). A descriptive modal of discourse in the corrective treatment of learners' errors. Language Learning, 27(1), 29-46.

Chomsky, N. (1957). Syntactic structures. The Hague: Mouton.

Chomsky, N. (1966). Linguistic theory. In J. P. B. Allen \& P. Van Buren (Eds.), Chomsky: Selected readings (pp. 152-159). London: Oxford University Press.

Corder, S. P. (1967). The significance of learners’ errors. International Review of Applied Linguistics, 5, 161-170.

Courchêne, R. (1980). The error analysis hypothesis, the contrastive analysis hypothesis and the correction of error in the second language classroom. TESL Talk, 11(3), 1-29.

DeBot, K. (1996). The psycholinguistics of the output hypothesis. Language Learning, 46, 529-555.

DeKeyser, R. M. (2005). What makes learning second language grammar difficult? A review of issues. In R. M. DeKeyser (Ed.), Grammatical development in language learning (pp. 1-25). Malden, M.A.: Blackwell Publishing.

DeKeyser, R. M. (2007a). Introduction: Situating the concept of practice. In R. M. DeKeyser (Ed.), Practice in second language: Perspectives from applied linguistics and cognitive psychology (pp. 1-18). New York, N.Y.: Cambridge University Press.

DeKeyser, R. M. (2007b). Skill acquisition theory. In B. VanPatten \& J. Williams (Eds.), Theories in second language acquisition: An introduction (pp. 97-113). Mahwah, N.J.: Lawrence Erlbaum Associates, Publishers.

Doughty, C., \& Pica, T. (1986). “Information gap” tasks: Do they facilitate second language acquisition?. TESOL Quarterly, 20, 305-325.

Doughty, C., \& Varela, E. (1998). Communicative focus on form. In C. Doughty \& J. Williams (Eds.), Focus on form in classroom second language acquisition (pp. 114-138). New York, N.Y.: Cambridge University Press.

Egi, T. (2007). Recasts, learners' interpretations, and L2 development. In A. Mackey (Ed.), Conversational interaction in second language acquisition: A collection of empirical studies (pp. 249-267). Oxford: Oxford University Press.

Ellis, N. C. (2002). Frequency effects in language processing. Studies in Second Language Acquisition, 24, 143-188.

Ellis, N. C. (2005). At the interface: Dynamic interactions of explicit and implicit language knowledge. Studies in Second Language Acquisition, 27, 305-352.

Ellis, R. (2006). Researching the effects of form-focussed instruction on L2 acquisition. AILA Review, 19, 18-41.

Ellis, R., Loewen, S., \& Erlam, R. (2006). Implicit and explicit corrective feedback and the acquisition of L2 grammar. Studies in Second Language Acquisition, 28, 339-368. 
Gass, S. M. (1997). Input, interaction and the second language learner. Mahwah, N.J.: Lawrence Erkbaum Associates, Publishers.

Gass, S. M., \& Mackey, A. (2007). Input, interaction and output in second language acquisition. In B. VanPatten \& J. Williams (Eds.), Theories in second language acquisition: An introduction (pp. 175-199). Mahwah, N.J.: Lawrence Erlbaum Associates, Publishers.

Gass, S. M., \& Selinker, L. (2001). Second language acquisition: An introductory course (2nd ed.). Mahwah, N.J.: Lawrence Erlbaum Associates, Publishers.

Harley, B., \& Swain, M. (1984). The interlanguage of immersion students and its implications for second language teaching. In A. Davies, C. Criper, \& A. Howatt (Eds.), Interlanguage (pp. 291-311). Edinburgh: Edinburgh University Press.

Jordan, G. (2004). Theory construction in second language acquisition. Philadelphia, P.A.: John Benjamins Publishing Company. Kim, J. H., \& Han, Z. (2007). Recasts in communicative EFL classes: Do teacher intent and learner interpretation overlap?. In A. Mackey (Ed.), Conversational interaction in second language acquisition: A collection of empirical studies (pp. 269-297). Oxford: Oxford University Press.

Krashen, S. (1982). Principles and practice in second language acquisition. Englewood Cliffs, N.J.: Prentice-Hall.

Krashen, S. (1985). The input hypothesis: Issues and implications. New York, N.Y.: Longman.

Larsen-Freeman, D., \& Long, M. H. (1991). An introduction to second language acquisition research. New York, N.Y.: Longman.

Leeman, J. (2003). Recasts and second language development: Beyond negative evidence. Studies in Second Language Acquisition, 25, 35-63.

Lightbown, P. M., \& Spada, N. (1990). Focus-on-form and corrective feedback in communicative language teaching: Effects on second language learning. Studies in Second Language Acquisition, 12, 429-448.

Lightbown, P. M., \& Spada, N. (1994). An innovative program for primary ESL in Quebec. TESOL Quarterly, 28, 563-573.

Long, M. H. (1983). Native speaker/non-native speaker conversation and negotiation of comprehensible input. Applied Linguistics, 4(2), 126-141.

Long, M. H. (1991). Focus on form: A design feature in language teaching methodology. In K. de Bot, R. Ginsberg, \& C. Kramsch (Eds.), Foreign language research in cross-cultural perspective (pp. 39-52). Philadelphia, P.A.: John Benjamins Publishing Company.

Long, M. H. (1993). Assessment strategies for second language acquisition theories. Applied Linguistics, 14, 225-249.

Long, M. H. (1996). The role of the linguistic environment in second language acquisition. In W. C. Ritchie \& T. K. Bhatia (Eds.), Handbook of language acquisition (Vol. 2): Second language acquisition (pp. 413-468). New York: Academic Press.

Long, M. H. (2007). Problems in SLA. Mahwah, N.J.: Lawrence Erlbaum Associates, Publishers.

Long, M. H., \& Robinson, P. (1998). Focus on form: Theory, research, and practice. In C. Doughty \& J. Williams (Eds.), Focus on form in classroom second language acquisition (pp. 15-41). New York, N.Y.: Cambridge University Press.

Lyster, R. (1998a). Recasts, repetition, and ambiguity in L2 classroom discourse. Studies in Second Language Acquisition, 20, 51-81.

Lyster, R. (1998b). Negotiation of form, recasts and explicit correction in relation to error types and learner repair in immersion classrooms. Language Learning, 48, 183-218.

Lyster, R. (2004). Differential effects of prompts and recasts on form-focused instruction. Studies in Second Language Acquisition, 26, 399-432.

Lyster, R., \& Izquierdo, J. (2009). Prompts versus recasts in dyadic interaction. Language Learning, 59, 453-498.

Lyster, R., \& Ranta, L. (1997). Corrective feedback and learner uptake: Negotiation of form in communicative classrooms. Studies in Second Language Acquisition, 19, 37-66.

Mackey, A., \& Philp, J. (1998). Conversational interaction and second language development: Recasts, responses, and red herrings?. The Modern Language Journal, 82, 338-356.

Mackey, A., Gass, S. M., \& McDonough, K. (2000). How do learners perceive implicit negative feedback?. Studies in Second Language Acquisition, 22, 471-497.

Mackey, A., Philp, J., Egi, T., Fujii, A., \& Tasumi, T. (2002). Individual differences in working memory, noticing of interactional feedback in L2 development. In P. Robinson (Ed.), Individual differences and instructed language learning (pp. 181-209). Philadelphia, P.A.: John Benjamins Publishing Company.

McDonough, K. (2005). Identifying the impact of negative feedback and learners' responses on ESL development. Studies in Second Language Acquisition, 27(1), 79-103. 
McDonough, K. (2007). Interactional feedback and the emergence of simple past activity verbs in L2 English. In A. Mackey (Ed.), Conversational interaction in second language acquisition: A series of empirical studies (pp. 323-338). Oxford: Oxford University Press.

McLaughlin, B. (1987). Theories of second language learning. London, UK: Edward Arnold (Publishers) Ltd..

Ortega, L. (2007). Second language learning explained? SLA across nine contemporary theories. In B. VanPatten \& J. Williams

(Eds.), Theories in second language acquisition: An introduction (pp. 225-250). Mahwah, N.J.: Lawrence Erlbaum Associates, Publishers.

Ortega, L. (2009). Understanding second language acquisition. London, UK: Hodder Education.

Panova, I., \& Lyster, R. (2002). Patterns of corrective feedback and uptake in an adult ESL classroom. TESOL Quarterly, 36, 573-595.

Philp, J. (2003). Constraints on "noticing the gap": Nonnative speakers; noticing of recasts in NS-NNS interaction. Studies in Second Language Acquisition, 25, 99-126.

Pica, T. (1994). Research on negotiation: What does it reveal about second language learning conditions, processes, and outcomes?. Language Learning, 44(3), 493-527.

Popper, K. R. (2008). The two fundamental problems of the theory of knowledge. New York: Routledge.

Ranta, L., \& Lyster, R. (2007). A cognitive approach to improving immersion students' oral language abilities: The awareness-practice-feedback sequence. In R. DeKeyser (Ed.), Practice in second language: Perspectives from applied linguistics and cognitive psychology (pp. 141-160). New York, N.Y.: Cambridge University Press.

Robinson, P. (1995). Attention, memory and the “Noticing Hypothesis”. Language Learning, 45, 283-331.

Sato, C. J. (1990). The syntax of conversation in interlanguage development. Tubingen: Gunter Narr.

Schmidt, R. (1983). Interaction, acculturation, and the acquisition of communicative competence. In N. Wolfson \& E. Judd (Eds.), Sociolinguistics and language acquisition (pp. 137-174). Rowley, M.A.: Newbury House.

Schmidt, R. (1990). The role of consciousness in second language learning. Applied Linguistics, 11, 129-158.

Schmidt, R. (1994). Deconstructing consciousness in search of useful definitions for applied linguistics. AILA Review, 11, 11-26.

Schmidt, R. (1995). Consciousness and foreign language learning: A tutorial on the role of attention and awareness in learning. In R. Schmidt (Ed.), Attention and awareness in foreign language learning (pp. 1-63). Honolulu: Hawai'i: University of Hawai'i, Second Language Teaching and Curriculum Center.

Schmidt, R. (2001). Attention. In P. Robinson (Ed.), Cognition and second language instruction (pp. 3-32). Cambridge: Cambridge University Press.

Schmidt, R., \& Frota, S. (1986). Developing basic conversational ability in second language: A case study of an adult learner of Portuguese. In R. Day (Ed.), Talking to learn: Conversation in second language acquisition (pp. 237-326). Rowley, M.A.: Newbury House.

Segalowitz, N. (2003). Automaticity in second languages. In C. J. Doughty \& M. H. Long (Eds.), Handbook of second language acquisition (pp. 382-408). Malden, M.A.: Blackwell.

Sheen, Y. (2004). Corrective feedback and learner uptake in communicative classrooms across instructional settings. Language Teaching Research, 8, 263-300.

Sheen, Y. (2007). The effects of corrective feedback, language aptitude, and learner attitudes on the acquisition of English articles. In A. Mackey (Ed.), Conversational interaction in second language acquisition: A collection of empirical studies (pp. 301-322). Oxford: Oxford University Press.

Sheen, Y. (2011). Corrective feedback, individual differences and second language learning. New York, N.Y.: Springer London Limited.

Skehan, P. (1998). A cognitive approach to language learning. Oxford: Oxford University Press.

Skinner, B. F. (1957). Verbal behavior. New York: Appleton-Century-Crofts.

Swain, M. (1985). Communicative competence: Some roles of comprehensible input and comprehensible output in its development. In S. Gass \& C. Madden (Eds.), Input in second language acquisition (pp. 235-253). Rowley, M.A.: Newbury House.

Swain, M. (1993). The output hypothesis: Just speaking and writing aren’t enough. The Canadian Modern Language Review, 50, 158-164.

Swain, M. (1995). Three functions of output in second language learning. In G. Cook \& B. Seidlhofer (Eds.), Principle and practice in applied linguistics (pp. 124-144). Oxford: Oxford University Press. 
Swain, M. (1998). Focus on form through conscious reflection. In C. Doughty \& J. Williams (Eds.), Focus on form in classroom second language acquisition (pp. 64-81). Cambridge: Cambridge University Press.

Swain, M., \& Lapkin, S. (1995). Problems in output and the cognitive processes they generate: A step towards second language learning. Applied Linguistics, 16, 371-391.

Tomlin, R., \& Villa, V. (1994). Attention in cognitive science and SLA. Studies in Second Language Acquisition, 16, $183-204$.

Trofimovich, P., Ammar, A., \& Gatbonton, E. (2007). How effective are recasts? The role of attention, memory, and analytical ability. In A. Mackey (Ed.), Conversational interaction in second language acquisition: A collection of empirical studies (pp. 171-195). Oxford: Oxford University Press.

Truscott, J. (1996). The case against grammar correction in L2 writing classes. Language Learning, 46, 327-369.

Tulving, E. (2002). Episodic memory: From mind to brain. Annual Review of Psychology, 53, 1-25.

VanPatten, B. (1990). Attending to form and content in the input: An experiment in consciousness. Studies in Second Language Acquisition, 12(3), 287-301.

VanPatten, B. (2002). Processing instruction: An update. Language Learning, 52, 755-803.

VanPatten, B. (2004). Input and output in establishing form-meaning connections. In B. VanPatten, J. Williams, S. Rott, \& M. Overstreet (Eds.), Form-meaning connections in second language acquisition (pp. 29-47). Mahwah, N.J.: Lawrence Erlbaum Associates, Publishers.

VanPatten, B. (2007). Input processing in adult second language acquisition. In B. VanPatten \& J. Williams (Eds.), Theories in second language acquisition: An introduction (pp. 115-136). Mahwah, N.J.: Lawrence Erlbaum Associates, Publishers.

VanPatten, B., \& Williams, J. (2007a). The nature of theories. In B. VanPatten \& J. Williams (Eds.), Theories in second language acquisition: An introduction (pp. 1-16). Mahwah, N.J.: Lawrence Erlbaum Associates, Publishers.

VanPatten, B., \& Williams, J. (2007b). Early theories in second language acquisition. In B. VanPatten \& J. Williams (Eds.), Theories in second language acquisition: An introduction (pp. 17-35). Mahwah, N.J.: Lawrence Erlbaum Associates, Publishers.

White, L. (1987). Against comprehensible input: The input hypothesis and the development of L2 competence. Applied Linguistics, 8, 95-110. 